\title{
Short Illustrated Review Ependymoma of conus medullaris presenting as subarachnoid haemorrhage
}

\author{
C. T. Ulrich, J. Beck, V. Seifert, G. Marquardt \\ Neurosurgical Clinic, Johann Wolfgang Goethe-University, Frankfurt/Main, Germany
}

Received 12 March 2007; Accepted 11 September 2007; Published online 7 December 2007

(C) Springer-Verlag 2007

\begin{abstract}
Summary
Subarachnoid haemorrhage (SAH) due to spinal ependymoma is very rare. We report a 37 year old man who presented with typical clinical signs of SAH. Lumbar puncture confirmed SAH but cerebral angiography was negative, and further diagnostic work-up revealed an ependymoma of the conus medullaris as the source of the haemorrhage. A comprehensive review of the literature was conducted. Only 17 patients with spontaneous SAH due to a spinal ependymoma have been reported since 1958. However, in cases of SAH and negative diagnostic findings for cerebral aneurysms or malformations, this aetiology should be considered and work-up of the spinal axis completed.
\end{abstract}

Keywords: Spinal ependymoma; subarachnoid haemorrhage.

\section{Abbreviations \\ $C T$ Computer tomography \\ $S A H$ Subarachnoid haemorrhage}

\section{Introduction}

Spontaneous subarachnoid haemorrhage (SAH) due to a spinal ependymoma is a very rare entity. Approximately less than $1 \%$ of SAH is caused by spinal lesions $[1,3,8$,

Correspondence: Christian T. Ulrich, Neurosurgical Clinic, Johann Wolfgang Goethe-University, Frankfurt/Main, Germany. e-mail: ulrich@med.uni-frankfurt.de
15]. Low-back pain and severe headaches are often the leading clinical features. We present a patient who had diagnostic work-up for intracranial SAH but was found to have an ependymoma of the conus medullaris as the source of haemorrhage. A thorough review of this very rare condition was performed.

\section{Literature review and analysis}

We searched the PubMed database (www.ncbi.nlm.nih. gov/entrez/query.fcgi?db $=$ PubMed) for "spinal ependymoma subarachnoid haemorrhage" and found 39 queries up to December 2006. Furthermore, we reviewed the references of the relevant literature. Twelve authors were found in the English and German literature, reporting about 17 patients with spinal ependymoma who presented with typical clinical features of SAH since 1958

We reviewed the location, clinical presentation, the diagnostic evaluation and the time from onset of symptoms to diagnosis (Table 1). There were 13 males and 4 females; the median age was 31.35 years. All patients reported had histologically proven ependymomas. All tumours except one, in the lower thoracic spine, were located in the lumbar region. The most common symptoms were headaches, low-back, and leg pain. In 8 patients, headache was predominant compared to the backache. Cranial computer tomography was performed in seven patients. Of these, only one was positive and six were negative for blood. Lumbar puncture revealed bloody or xanthochromic cerebrospinal fluid in 15 patients. Cerebral panangiography was done in nine pa- 
Table 1. Summary of cases with SAH due to spinal ependymomas

\begin{tabular}{|c|c|c|c|c|c|c|c|c|c|}
\hline Ref. & $\begin{array}{l}\text { Patient } \\
\text { no. }\end{array}$ & Gender & $\begin{array}{l}\text { Age } \\
(y)\end{array}$ & Location & Symptoms & $\begin{array}{l}\text { Cranial CT } \\
\text { for blood }\end{array}$ & $\begin{array}{l}\text { Lumbar } \\
\text { puncture }\end{array}$ & $\begin{array}{l}\text { Cerebral } \\
\text { panangiography }\end{array}$ & $\begin{array}{l}\text { Time from } \\
\text { onset to } \\
\text { diagnosis }\end{array}$ \\
\hline [11] & 1 & M & 25 & L 4 intradural & $\begin{array}{l}\text { low-back pain, } \\
\text { headache }\end{array}$ & not performed & xanthochromic & $\begin{array}{l}\text { no bleeding } \\
\text { source }\end{array}$ & 7 months \\
\hline [13] & 2 & M & 22 & L 5 intradural & $\begin{array}{l}\text { low-back pain, } \\
\text { headache }\end{array}$ & not performed & bloody & $\begin{array}{l}\text { no bleeding } \\
\text { source }\end{array}$ & 3 months \\
\hline [13] & 3 & M & 74 & L 1 intradural & $\begin{array}{l}\text { papilloedema, } \\
\text { vomitting, low-back } \\
\text { pain, headache }\end{array}$ & not performed & xanthochromic & not performed & 1 month \\
\hline [13] & 4 & M & 15 & L 1-2 intradural & $\begin{array}{l}\text { low-back pain, } \\
\text { headache }\end{array}$ & not performed & $\begin{array}{l}\text { bloody - } \\
\quad \text { xanthochromic }\end{array}$ & not performed & 9 days \\
\hline [7] & 5 & $\mathrm{~F}$ & 40 & $\begin{array}{l}\text { L 3-S } 1 \\
\text { intradural }\end{array}$ & $\begin{array}{l}\text { loss of vision, low-back } \\
\text { pain, headache }\end{array}$ & not performed & xanthochromic & not performed & 60 months \\
\hline [6] & 6 & $\mathrm{~F}$ & 29 & L 3 intradural & headache, leg pain & not performed & not obtained & $\begin{array}{l}\text { no bleeding } \\
\text { source }\end{array}$ & 63 months \\
\hline [6] & 7 & M & 15 & L 3 intradural & headache, low-back pain & not performed & unknown & $\begin{array}{l}\text { no bleeding } \\
\text { source }\end{array}$ & 12 months \\
\hline [6] & 8 & M & 17 & L 2 intradural & $\begin{array}{l}\text { headache, low-back pain, } \\
\text { sphincter distubance }\end{array}$ & not performed & bloody & $\begin{array}{l}\text { no bleeding } \\
\text { source }\end{array}$ & 12 months \\
\hline [14] & 9 & M & 35 & Th 9 intradural & headache, low-back pain & positive & bloody & $\begin{array}{l}\text { no bleeding } \\
\text { source }\end{array}$ & 40 days \\
\hline [8] & 10 & M & 31 & L 3-4 intradural & $\begin{array}{l}\text { headache, photophobia, } \\
\text { vomiting }\end{array}$ & negative & xanthochromic & $\begin{array}{l}\text { no bleeding } \\
\text { source }\end{array}$ & 3 months \\
\hline [12] & 11 & M & 14 & L 1-2 intradural & $\begin{array}{l}\text { headache, nausea, } \\
\text { vomiting, } \\
\text { low-back pain }\end{array}$ & negative & bloody & $\begin{array}{l}\text { no bleeding } \\
\text { source }\end{array}$ & $\begin{array}{l}\text { several } \\
\text { months }\end{array}$ \\
\hline [1] & 12 & M & 23 & L 1-2 intradural & $\begin{array}{l}\text { headache, low-back } \\
\text { pain }\end{array}$ & negative & bloody & $\begin{array}{l}\text { no bleeding } \\
\text { source }\end{array}$ & 14 days \\
\hline [15] & 13 & $\mathrm{~F}$ & 16 & L 2-3 intradural & $\begin{array}{l}\text { headache, vomiting, } \\
\text { low-back pain }\end{array}$ & negative & bloody & just considered & 10 months \\
\hline [10] & 14 & $\mathrm{~F}$ & 65 & L 2-3 intradural & $\begin{array}{l}\text { low-back pain, } \\
\text { headache, cauda } \\
\text { equina, motor deficits }\end{array}$ & not performed & xanthochromic & not performed & 12 months \\
\hline [4] & 15 & M & 36 & L 2 intradural & $\begin{array}{l}\text { low-back pain, headache, } \\
\text { motor deficits }\end{array}$ & negative & xanthochromic & not performed & 5 days \\
\hline [4] & 16 & M & 46 & L 5 intradural & $\begin{array}{l}\text { low-back pain, headache, } \\
\text { motor deficits }\end{array}$ & negative & xanthochromic & not performed & 10 days \\
\hline [2] & 17 & M & 30 & L 2 intradural, & low-back pain, headache & not performed & bloody & not performed & unknown \\
\hline $\begin{array}{l}\text { Current } \\
\text { report }\end{array}$ & 18 & M & 37 & L 1-2 intradural & headache, leg pain & negative & xanthochromic & $\begin{array}{l}\text { no bleeding } \\
\text { source }\end{array}$ & 16 days \\
\hline
\end{tabular}

tients without any evidence of a source of bleeding. The median time from onset of symptoms to diagnosis was approximately one year (353.53 days).

\section{Case report}

A 37 year old man who complained of severe headaches, nausea, and vomiting for two days presented at an outside hospital. He also reported pain in both legs. The medical history was significant for an acute hearing loss two months previously. He received medication including, cortisone, and aspirin.

SAH (Hunt \& Hess grade II) was suspected and a cranial CT scan was performed, which was negative for blood. A lumbar puncture with a three tube test, however, revealed a positive finding for xanthochromic cerebrospinal fluid.

The patient was referred to our department for further diagnosis and treatment. The patient's mental status was normal. There was slight nuchal meningism and also bilateral positive Lasègue sign. The neurological examination was otherwise normal. The day after admission a cerebral angiogram was performed, but a cerebral aneurysm or vascular malformation could not be found. Also, MRI of the cervical and thoracic spine showed no evidence of a bleeding source. Finally, MRI of the lumbar spine revealed a $3 \mathrm{~cm}$ intradural mass at the level of L1/2 (Fig. 1). Furthermore, multiple small lumbar and sacral masses were present. The patient underwent surgery for a suspected ependymoma. Intraoperatively, a 


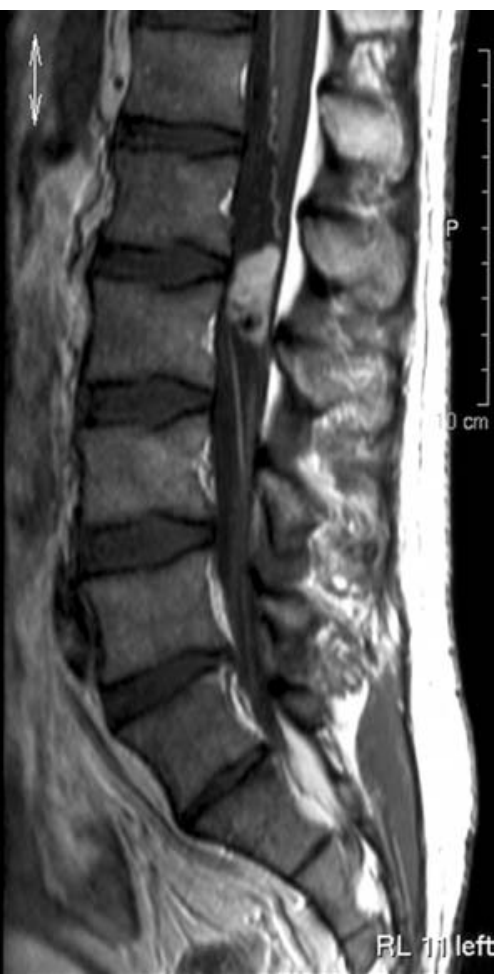

Fig. 1. MRI of the lumbar spine with ependymoma at the level of $\mathrm{L} 1 / 2$

highly vascular tumour was removed. The histological examination of the tissue confirmed the diagnosis of an ependymoma (WHO grade I). The tumour was resected without any sequelae.

\section{Discussion}

The vast majority of patients with acute onset of SAH are found to have intracranial lesions, most often aneurysms or arteriovenous malformations. In some patients SAH is caused by brain tumours, vasculitis, or secondary to infarction [17]. SAH due to spinal lesions, however, is very rare. Walton [17] analysed 312 patients with $\mathrm{SAH}$ and found the bleeding originating from intraspinal lesions in only 2 both of which were angiomas. Other authors report a rare incidence of SAH due to spinal origin, accounting for less than $1 \%$ of all cases [1, 3, $8,15]$. The most common aetiologies are spinal trauma, arteriovenous malformations, and aneurysms of spinal arteries [5]. Spinal cord masses like ependymomas, nerve sheath tumours, hemangioblastomas, metastasis, or meningiomas may also cause SAH. Therefore, the tumour histology seems to be an important factor for the incidence of bleeding. In relation to SAH of spinal origin the most frequent $(60 \%)$ pathology is ependymoma [4].
Our patient presented with typical signs and symptoms of SAH. The diagnostic approach was according to the standard protocol, but cranial CT was negative for blood. Therefore, a lumbar puncture with the three tube test was done with a positive result. Cerebral angiography as well as cervical and thoracic MRI revealed no bleeding source. In view of persistent leg pain a lumbar MRI was performed and showed an ependymoma of the conus medullaris as the source of bleeding.

Also, the patient's past medical history revealed acute hearing loss. This may indicate preliminary bleeding from the lumbar ependymoma, since there are several descriptions of superficial cerebral siderosis caused by chronic subarachnoid haemorrhage entailing hearing loss, ataxia and other symptoms $[9,16]$. However, the result of deposition of haemosiderin is a proliferation of microglia and astrocytes as well as axonal spheroid swelling. The eighth cranial nerve and the cerebellar cortex are described as particularly vulnerable to the ferritin metabolites $[9,16]$.

Spinal ependymoma presenting as SAH is very rare. Including the current example, only 18 patients have been reported so far. Nonetheless, this aetiology should be considered in the event of negative diagnostic findings for vascular malformations in a patient with $\mathrm{SAH}$, and a work-up of the spinal axis should be completed.

\section{References}

1. Admiraal P, Hazenberg GJ, Algra PR, Kamphorst W, Wolbers JG (1992) Spinal subarachnoid haemorrhage due to a filum terminale ependymoma. Clin Neurol Neurosurg 94: 69-72

2. Argyropoulou PI, Argyropoulou MI, Tsampoulas C, Gogos P, Manavis I, Efremidis SC (2001) Myxopapillary ependymoma of the conus medullaris with subarachnoid haemorrhage: MRI in two cases. Neuroradiology 43: 489-491

3. Cerejo A, Vaz R, Feyo PB, Cruz C (1990) Spinal cord haemangioblastoma with subarachnoid haemorrhage. Neurosurgery 27 : 991-993

4. Cervoni L, Franco C, Celli P, Fortuna A (1995) Spinal tumors and subarachnoid haemorrhage: pathogenetic and diagnostic aspects in 5 cases. Neurosurg Rev 18: 159-162

5. Cummings TM, Johnson MH (1994) Neurofibroma manifested by spinal subarachnoid haemorrhage. Am J Roentgenol 162: 959-960

6. Dijindjian M, Djindjian R, Houdart R, Hurth M (1978) Subarachnoid haemorrhage due to intraspinal tumors. Surg Neurol 9: $223-229$

7. Gibberd FB, Ngan H, Swann GF (1972) Hydrocephalus, subarachnoid haemorrhage and ependymomas of the cauda equina. Clin Radiol 23: 422-426

8. Hawkins CP, Heron JR (1988) Subarachnoid haemorrhage from spinal tumor (in the absence of spinal symptoms or signs). J Neurol Neurosurg Psychiatry 51: 305-307 
9. Leussink VI, Flachenecker P, Brechtelsbauer D, Bendszus M, Sliwka U, Gold R, Becker G (2003) Superficial siderosis of the central nervous system: pathogenetic heterogeneity and therapeutic approaches. Acta Neurol Scand 107: 54-61

10. Malbrain ML, Kamper AM, Lambrecht GL, Hermans P, Baeck E, Verhoeven F, Wyffels G, Verbraeken H (1994) Filum terminale ependymoma revealed by acute cauda equina compression syndrome following intratumoral and spinal subarachnoid haemorrhage in a patient on oral anticoagulants. Acta Neurol Belg 94: $35-43$

11. Mendelsohn RA, Mora F (1958) Spontaneous subarachnoid haemorrhage caused by ependymoma of filum terminale. J Neurosurg 15: $460-463$

12. Mestayer RJ, Deveikis JP, Schellinger D, Patronas NJ, Stull MA (1990) Neuroradiology case of the day. Subarachnoid haemorrhage complicating an ependymoma of cauda equina. Am J Roentgenol 154: 1342

13. Nassar SI, Correll JW (1968) Subarachnoid haemorrhage due to spinal cord tumors. Neurology 18: 87-94

14. Papo I, Balint K, Slovik F, Scarpelli M, Ranaldi R (1985) Subarachnoid haemorrhage due to widely metastatising malignant ependymoma. Neurochirurgia (Stuttg) 28: 243-245

15. Shen WC, Ho YJ, Lee SK, Lee KR (1993) Ependymoma of the cauda equina presenting with subarachnoid hemorrhage. Am J Neuroradiol 14: 399-400

16. Vibert D, Hausler R, Lovblad KO, Schroth G (2004) Hearing loss and vertigo in superficial siderosis of the central nervous system. Am J Otolaryngol 25: 142-149

17. Walton JN (1953) Subarachnoid haemorrhage of unusual aetiology. Neurology 3: 517-543 